\title{
RANCANG BANGUN SISTEM MONITORING TEMPAT SAMPAH RUMAH TANGGA DAN PENERANGAN JALAN BERBASIS WIRELES SENSOR NETWORK (WSN)
}

\author{
Muhamad Syaifudin*), Faqih Rofii, Anis Qustoniah \\ Jurusan Teknik Elektro, Universitas Widyagama Malang \\ Kampus III, Jl. Taman Borobudur Indah No. 3 Malang, Indonesia 65142 \\ ${ }^{*}$ E-mail: msyaifudin589@gmail.com
}

\begin{abstract}
Abstrak
Wireless sensor network (WSN) merupakan suatu jaringan yang terbentuk dari beberapa node sensor yang bersifat individu, yang ditempatkan pada suatu tempat untuk memonitor keadaan yang bisa berinteraksi dengan lingkungan sekitar. Xbee merupakan suatu komponen dari wireless sensor network yang dapat digunakan, karena perangkat ini merupakan perangkat yang handal yang terdiri dari receiver dan transmitter. Dirancang suatu sistem pemantauan volume tempat sampah dan lampu penerangan jalan dengan menggunakan sensor ultrasonik pada tempat sampah dan photodioda pada lampu penerangan jalan, sehingga saat kondisi volume tempat sampah dan lampu penerangan jalan mengalami perubahan maka Xbee akan mengirimkan informasi ke ruang petugas. Sistem pemantauan menghasilkan output RW1,11,0\# menunjukkan bahwa alamat yang dikirim adalah dari RW 1. Kondisi jarak sensor volume adalah 11 $\mathrm{cm}$, ketika jarak volume sampah sudah mencapai $5 \mathrm{~cm}$ atau di bawahnya maka progres bar akan berwarna biru hampir penuh sehingga buzzer di ruang petugas akan berbunyi. Hasil pengujian menunjukkan kondisi keadaan lampu penerangan jalan ketika dalam kondisi mati maka alamat yang dikirimkan adalah 0 dan indikator lampu berwarna putih, sedangkan ketika lampu penerangan jalan dalam kondisi menyala maka alamat yang akan dikirimkan adalah 1 serta indikator lampu pada sistem monitoring akan menyala. Diperoleh kesimpulan jarak aman jangkauan Xbee dari tempat sampah ke ruang petugas sejauh 30 meter (dalam ruang) dan 80 meter (luar ruang).
\end{abstract}

Kata kunci: wireless sensor network, xbee, tempat sampah, lampu penerangan

\begin{abstract}
Wireless sensor network (WSN) is a network that is formed from several individual sensor nodes, placed to monitor conditions of the surrounding environment. Xbee is a component of the wireless sensor network that can be used, because this device is a reliable device consisting of a receiver and transmitter. A system for monitoring the volume of trash bins and street lighting is designed by using ultrasonic sensors in the trash and photodiodes in street lighting, so that when the condition of the volume of trash and street lighting changes, Xbee will send information to the officer room. The monitoring system produces RW1,11,0 \# output indicating that the address sent is from RW 1 . The condition of the distance sensor volume is $11 \mathrm{~cm}$, when the volume of garbage has reached $5 \mathrm{~cm}$ or below, the progress bar will almost blue so that the buzzer is the officer room will ring. The test results show the condition of the street lighting when it is turned off, the address sent is 0 and the indicator lights are white, while when the street lights are on, the address to be sent is 1 and the indicator lights on the monitoring system will light up. It is concluded that the safe distance of Xbee from the trash can to the officer room is 30 meters (indoor) and 80 meters (outdoor).
\end{abstract}

Keywords: wireless sensor network, xbee, trash can, lighting

\section{Pendahuluan}

Perkembangan perangkat komputasi mobile dan jaringan nirkabel area lokal (wireless local area network - WLAN) telah mendorong meningkatnya minat di sistem locationaware dan layanannya. Wireless Sensor Network (WSN) atau jaringan sensor nirkabel merupakan suatu jaringan yang terdiri dari beberapa sensor node yang bersifat individu yang diletakkan ditempat-tempat yang berbeda untuk memonitoring kondisi suatu tempat dan dapat berinteraksi dengan lingkungannya dengan cara sensing, controlling dan communication terhadap parameterparameter fisiknya [1]. Secara umum Jaringan Sensor Nirkabel itu sendiri terdiri dari dua komponen, yaitu 
sensor sumber (node) dan sink. Node merupakan komponen kesatuan dari jaringan yang dapat menghasilkan informasi, biasanya merupakan sebuah sensor atau juga dapat berupa sebuah aktuator yang menghasilkan feedback pada keseluruhan operasi. Sink atau juga biasa disebut base station merupakan kesatuan yang mengumpulkan informasi dari node sehingga dapat dilakukan pengolahan informasi lebih lanjut [2].

Jaringan sensor nirkabel merupakan generasi baru dari sistem sensor (sensory system). Oleh karena itu masingmasing sensor dapat dikatakan sebagai sensor pintar. Beberapa jaringan sengaja didesain untuk dapat melakukan proses di jaringan (in-network processing), sehingga pengambilan keputusan dapat dilakukan di tempat (on the spot) atau setidaknya dapat melakukan konversi dan agregasi data sehingga sangat efisien untuk digunakan sebagi sistem komunikasi, sebelum ditransmisikan ke bagian pusat pemantauan [3]. Xbee series 2 modul RF dirancang untuk beroperasi dalam protokol ZigBee dengan biaya yang murah dan jaringan sensor nirkabel menggunakan daya yang rendah. Modul ini membutuhkan daya yang rendah dan dapat melakukan pengiriman data yang handal antara perangkat dengan jarak yang jauh. Modul ini beroperasi pada frekuensi 2.4 GHz. (Inc, XBee Series 2 OEM RF Modules, 2007) pengiriman data yang handal antara perangkat dengan jarak yang jauh. Xbee series 2 merupakan sebuah modul yang terdiri dari receiver dan transmitter. Melalui port serial ini Xbee dapat berkomunikasi secara UART (Universal Asincrhounus Recivier transmiter) sehingga sangat efisien digunakan sebagai modul untuk media transmisi monitoring tempat sampah dan penerangan jalan lingkungan pada suatu perumahan atau perkampungan karena setiap sensor dapat saling berkomunikasi tanpa kabel, maka teknologi ini dapat di-deploy ke area tak terjangkau dengan kerapatan tinggi bila diperlukan. Lalu kombinasi dari kemampuan memproses data, penyimpanan data (data storage) dan komunikasi secara nirkabel, juga memberikan nilai tambah bagi teknologi ini, karena data yang ditransmisikan dapat didistribusikan dengan algoritma yang cerdas, sehingga jaringan ini dapat melakukan pengaturan secara mandiri (self-organize) [4].

Pengembangan tempat sampah pintar dan monitoring penerangan jalan sendiri semakin pesat. Beberapa penulis telah mengembangkan tempat sampah pintar dan lampu penerangan jalan umum di antaranya tempat sampah yang bisa membuka dan menutup secara otomatis [5], pemantauan kondisi tempat sampah dengan modul GSM pelaporan via smartphone [6], monitoring lampu penerangan jalan umum menggunakan mikrokontroler arduino dan sensor ldr dengan notifikasi sms [7], dari beberapa jurnal yang ada memiliki kelemahan di antaranya tempat sampah yang hanya mengontrol membuka dan menutupnya saja tidak bisa memantau isi tempat sampah, lalu untuk tempat sampah dan penerangan jalan ada yang menggunakan modul GSM dirasa kurang cepat dan masih membutuhkan biaya pulsa dalam mengirimkan data, Sistem ini masih mengandalkan sinyal provider kartu telekomunikasi, sehingga apabila suatu saat jaringan telekomunikasi sedang down, maka pengiriman notifikasi pun ikut terganggu

Berdasarkan latar belakang di atas maka dirancang sistem monitoring tempat sampah rumah tangga dan penerangan jalan berbasis wireles sensor network (WSN), untuk meningkatkan keamanan lingkungan dan efisiensi dalam pengelolaan sampah. Pada sistem ini dibuat pendeteksi otomatis kondisi tempat sampah, setiap tempat sampah akan dipasang sensor ultrasonik HCSRF05, sedangkan setiap lampu penerangan jalan akan dipasang sensor photodioda. Ketika sensor tempat sampah pada level yang telah ditentukan tersebut terhalang dan photodioda mendeteksi kondisi lampu maka akan dikirim informasi keruang petugas dengan sistem WSN untuk ditampilkan pada layar LCD dan membunyikan buzzer di Ruang Petugas.

\section{Metode}

\section{a. Arduino uno}

Arduino Uno adalah board berbasis mikrokontroler pada ATmega328 . Board ini memiliki 14 pin digital input / output (dimana 6 pin dapat digunakan sebagai output PWM), 6 input analog, $16 \mathrm{MHz}$ osilator kristal, koneksi USB, konektor listrik, tombol reset. Pin-pin ini berisi semua yang diperlukan untuk mikrokontroler, hanya terhubung ke komputer dengan kabel USB atau sumber tegangan bisa didapat dari adaptor AC-DC atau baterai untuk menggunakannya [8]

\section{b. Sensor Ultrasonik}

Sensor ultrasonik digunakan untuk mengukur volume di dalam tempat sampah. Sensor ultrasonik ping adalah sensor $40 \mathrm{khz}$ produksi parallax. Kelebihan sensor ini adalah hanya membutuhkan 1 sinyal ( SIG ) selain jalur $5 \mathrm{v}$ dan ground. Sensor PING memancarkan gelombang ultrasonik sesuai dengan kontrol dari mikrokontroller pengendali ( pulse trigger dengan tout min 2 us) [9].

\section{c. Xbee}

Xbee merupakan modul RF yang bisa berfungsi sebagai pengirim sekaligus penerima dan beroperasi pada frekuensi $2.4 \mathrm{GHz}$. Radio ini diaplikasikan untuk mengirimkan data kondisi tempat sampah atau lampu penerangan jalan yang terhubung secara nirkabel (wireless) [10]. 


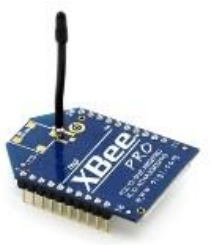

Gambar 1. Bentuk Xbee

\section{d. Photodioda}

Sensor Photodioda adalah suatu jenis dioda yang sensitif terhadap cahaya. Resistansinya berubah-ubah apabila terkena sinar cahaya yang dikirim oleh transmitter LED. Sensor photodioda sama seperti sensor LDR, mengubah besaran cahaya yang diterima sensor menjadi perubahan konduktansi [11].

\section{e. Buzzer}

Buzzer merupakan salah satu komponen elektronika yang berfungsi untuk mengubah getaran listrik menjadi getaran suara. prinsip kerja buzzer hampir sama dengan loud speaker [12].

\section{f. LCD (Liquid Cristal Display)}

LCD (Liquid Crystal Display) merupakan suatu jenis modul tampilan elektronik yang memiliki fungsi sebagai tampilan suatu data, baik karakter, huruf ataupun grafikan. LCD sangat berfungsi sebagai penampil yang nantinya akan digunakan untuk menampilkan kondisi volume sampah dan keadaan lampu penerangan jalan. Bentuk fisik dari LCD dapat dilihat pada Gambar 2.

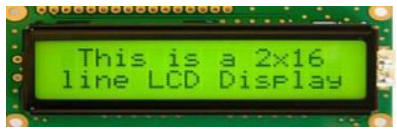

Gambar 2. Bentuk Fisik LCD

\section{g. Borland Delphi}

Borland Delphi merupakan suatu bahasa pemrograman yang bekerja dalam system operasi Windows. Delphi merupakan bahasa pemrograman yang efektif dan efisien karena memiliki cakupan kemampuan yang luas [13].

\section{Hasil dan Analisis}

\subsection{Blok Diagram Sistem Secara Umum}

Sistem monitoring volume tempat sampah rumah tangga dan penerangan jalan berbasis wireles sensor network (wsn) diilustrasikan dengan Gambar 3. Sistem kerja dimulai ketika sensor ultrasonik mendeteksi volume tempat sampah dan sensor photodioda mendeteksi cahaya pada lampu penerangan jalan, kemudian sinyal tersebut diolah oleh mikrokontroler arduino uno. Mikrokontroler mengolah data dari kedua sensor kemudian data tersebut akan dikirim oleh xbee pada alat yang selanjutnya data diterima oleh xbee pada ruang petugas dan ditampilkan oleh LCD (Liquid Crystal Display) serta di loging melalui PC untuk ditampilkan datanya, buzzer akan memberikan peringatan ketika volume sampah penuh .
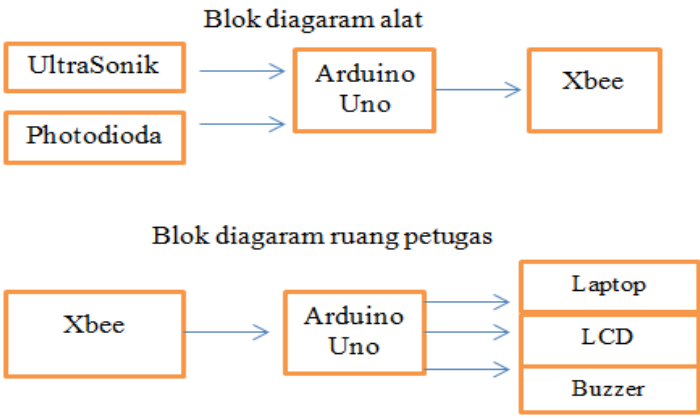

Gambar 3. Diagram Blok Sistem monitoring volume tempat sampah rumah tangga dan penerangan jalan berbasis wireles sensor network (wsn)

\subsection{Perencanaan Perangkat Keras}

Dalam perancangan perangkat keras dibutuhkan beberapa komponen pendukung mulai elektronik hingga perlengkapan mekanik agar sistem dapat bekerja dan berjalan dengan baik sesuai dengan fungsinya.

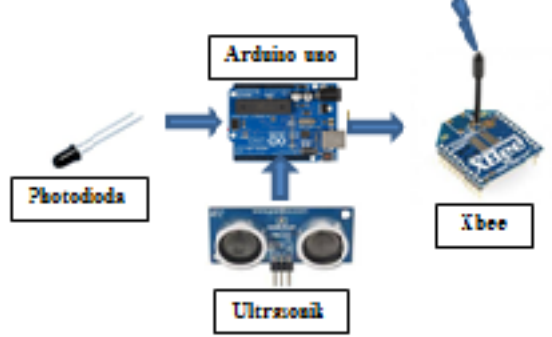

Gambar 4. Perancangan Perangkat Keras Alat

\subsubsection{Perancangan Perangkat Keras Pada Alat}

Rangkaian perangkat keras pada alat terdiri dari 4 komponen yaitu sensor ultrasonik, sensor photodioda, arduino dan xbee, seperti ditunjukkan pada Gambar 4.

\subsubsection{Perancangan Perangkat Keras Pada Ruang Petugas}

Rangkaian pada ruang petugas terdiri dari 5 komponen yaitu xbee sebagai penerima data, arduino mengolah data, buzzer memberikan peringatan, lcd dan laptop untuk menampilkan data/informasi yang dikirim oleh alat, seperti pada Gambar 5 . 


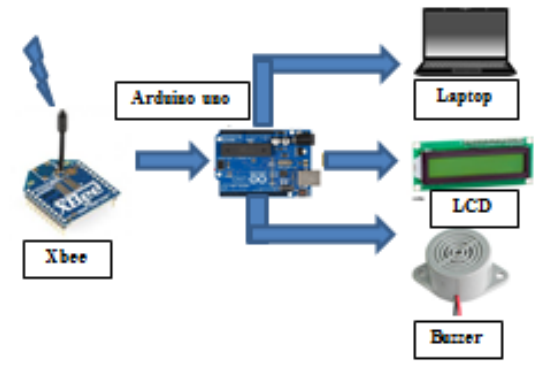

Gambar 5. Perancangan Perangkat Keras Ruang Petugas

\subsection{Perencanaan Perangkat Lunak}

Perancangan dan pembuatan perangkat lunak terdiri dari perancangan dan pembuatan perangkat lunak mikrokontroler Arduino. Gambar 6 menunjukkan flowchart sistem kerja pada tempat sampah dan lampu penerangan jalan.

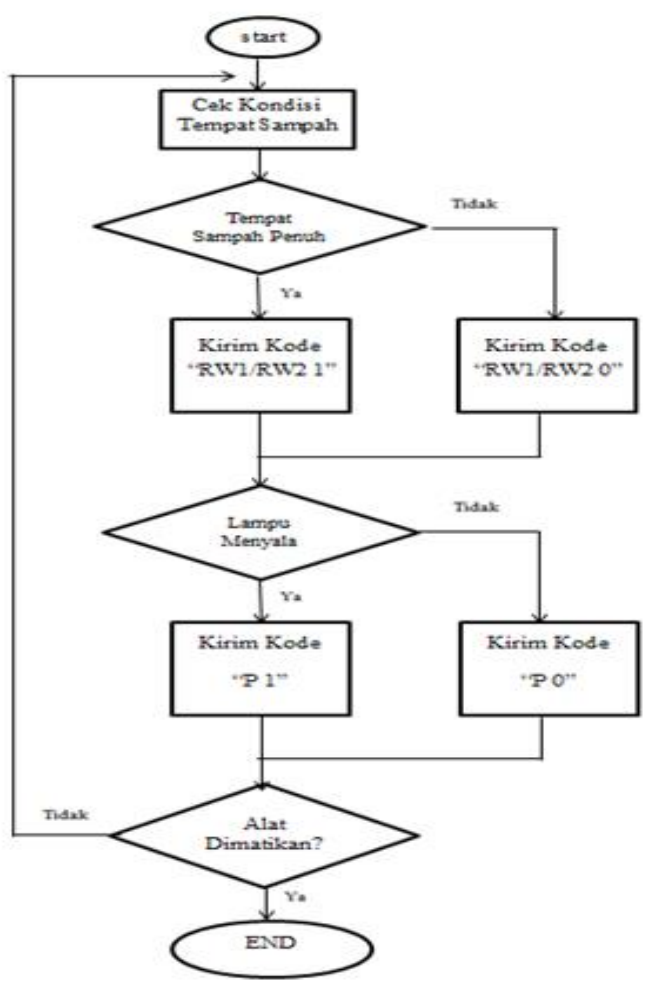

Gambar 6. Flowchart Tempat Sampah dan Lampu Penerangan jalan

Sistem kerja pada alat adalah dimulai dengan sensor ultrasonik mendeteksi keadaan volume tempat sampah apakah dalam kondisi penuh atau kosong, kemudian sensor photodioda mendeteksi kondisi lampu penerangan jalan menyala atau padam, setelah itu informasi akan diolah oleh arduino dan akan dikirimkan oleh xbee ke ruang petugas.
Pada ruang petugas perlu juga dibuat sebuah sistem untuk menampilkan informasi mengenai keadaan tempat sampah dan lampu penerangan jalan. Gambar 7 menjelaskan alur kerja sistem secara runtut.

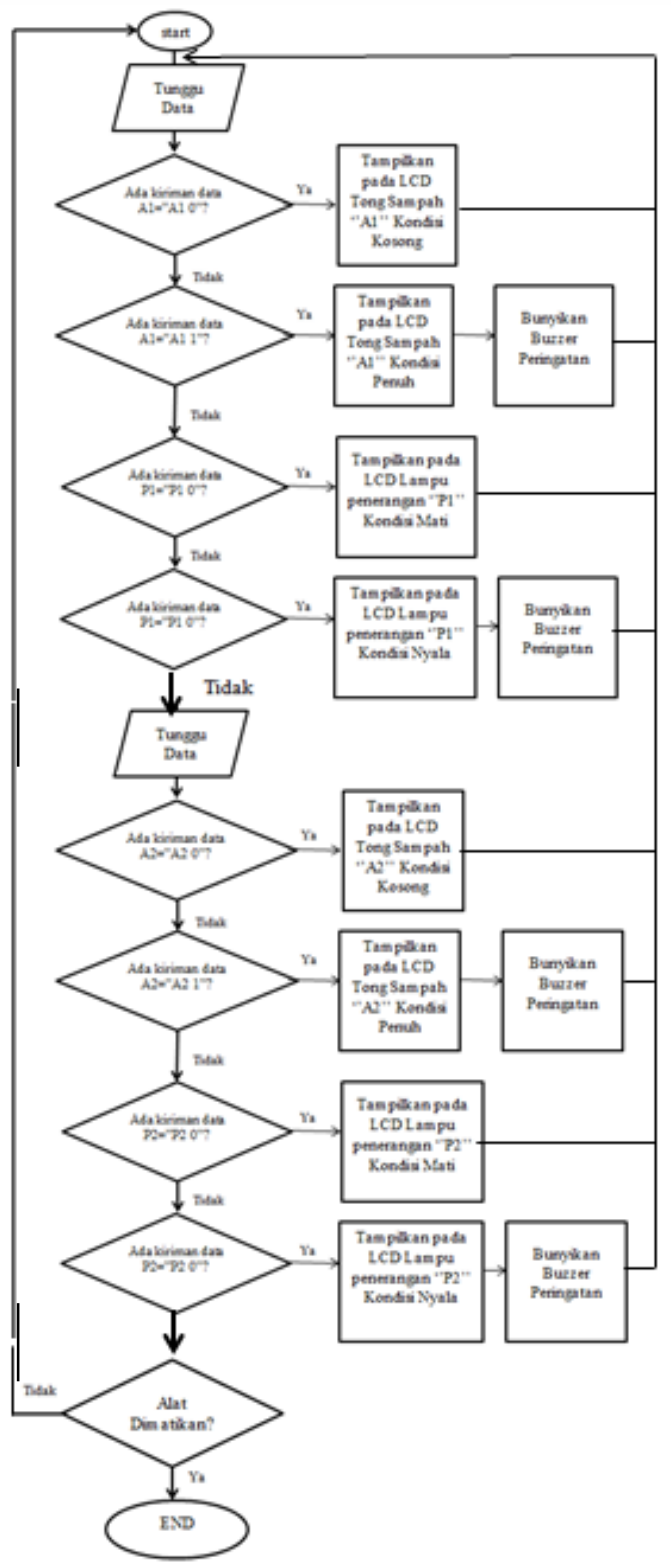

\section{Gambar 7. Flowchart Ruang Petugas}

Sistem kerja pada ruang petuagas dimulai dengan xbee menerima informasi yang dikirimkan oleh alat mengenai kedaan volume tempat sampah dan kondisi lampu penerangan jalan, informasi tersebut akan diterima secara terus menerus ketika tempat sampah dalam kondisi kosong maka diruang petugas dapat dipantau dengan 2 perangkat yaitu pada LCD atau laptop, saat kondisi tempat sampah dalam keadaan penuh makan buzzerpada ruang petugas akan berbunyi untuk memberikan 
peringatan mengenai keadaan tempat sampah dan lampu penerangan jalan.

\subsection{Pembuatan Sistem \\ 3.4.1. Hasil perancangan alat}

Alat yang berhasil dibuat pada penelitian ini adalah prototipe alat monitoring tempat sampah dan lampu penerangan jalan berbasis wireles sensor network (WSN), dimana kondisi tempat sampah dan lampu penerangan dapat dipantau diruang petugas secara berkala setiap ada perubahan keadaan pada alat dan PC/laptop (Gambar 8).
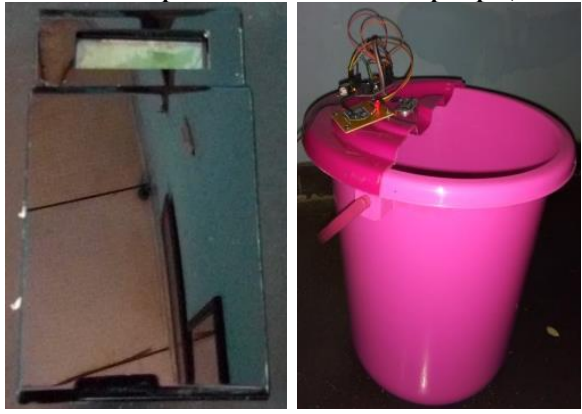

Gambar 8 Hasil perancangan alat

\subsubsection{Pengujian dan Analisa Alat}

\subsubsection{Pengujian sistem Arduino Uno}

Pada pengujian ini dilakukan untuk mengetahui bahwa System Arduino Uno dapat difungsikan sebagai input maupun output (I/O). pada pengujian ini sebuah LED dibutuhkan sebagai indikator Output dan saklar untuk pengujian Input.

Pengujian Arduino Uno sebagai output dilakukan untuk mengetahui fungsi pin yang ada pada Arduino Uno dapat bekerja dengan baik. Dalam pengujian pada pin 3 yaitu untuk menyalakan LED dengan kondisi aktif low, pada keadaan normal pin 3 di beri logika 0 maka LED menyala atau $L O W$, dan pada saat pin 3 diberi logika 1 maka lampu LED akan padam atau HIGH. Hasil dari pengujian ini dapat diketahui bahwa Arduino Uno dapat dijadikan sebagai Output. Hasil rangkaian pengujian Arduino Uno sebagai Output dapat dilihat pada Gambar 9.

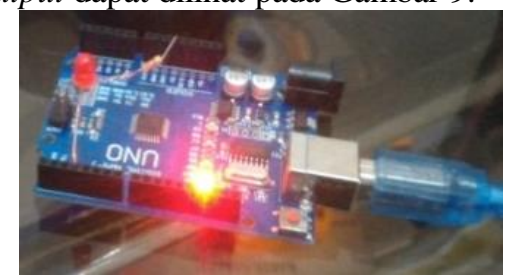

Gambar 9. Gambar pengujian Arduino Uno sebagai Output

Hasil pengujian sistem Arduino Uno apabila diberi logika 1 maka LED mati sedangkan logika 0 maka LED nyala. Hasil pengujian sistem ditunjukkan pada table 1
Tabel 1. Pengujian sistem Arduino Uno sebagai Output

\begin{tabular}{ll}
\hline Logika & LED PIN 3 \\
\hline 1 & HIGH \\
0 & LOW \\
\hline
\end{tabular}

Keterangan

$\mathrm{HIGH}=$ Mati

LOW = Nyala

Pada pengujian pada sistem Arduino Uno sebagai Input bertujuan untuk membuktikan bahwa pin pada Arduino Uno selain digunakan sebagai output juga dapat difungsikan sebagai input (masukan) untuk pin yang lain. Pada keadaan normal pin-pin pada Arduino Uno berlogika 1 menandakan $H I G H$. Dalam pengujian pada Arduino Uno dibutuhkan penambahan rangkaian button sebagai input ke pin 2 untuk menyalakan pin 13 yaitu sebagai indikator LED. Tambahan Rangkaian button pada Arduino Uno sebagai Input ditunjukkan pada gambar 10.
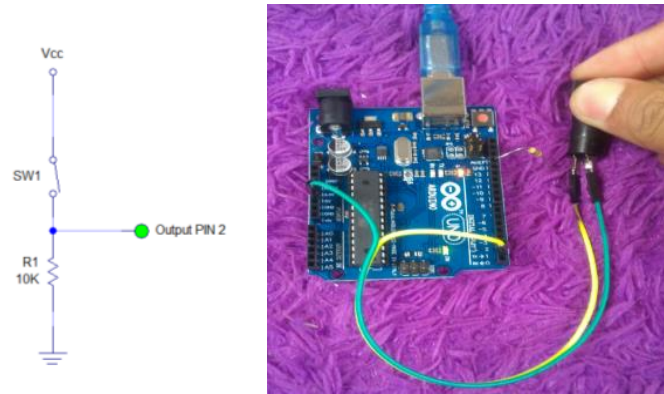

Gambar 10. Rangkaian tambahan button Arduino Uno

Penjelasan pada gambar di atas kaki button dihubungkan ke vec $5 \mathrm{~V}$, kemudian kaki button yang tersambung pada kaki resistor dihubungkan ke pin 2 dan kaki keluaran resistor dihubungkan ke ground. Hasil pengujian Arduino Uno pada Tabel 2.

Tabel 2. Pengujian Arduino Uno sebagai Input

\begin{tabular}{ll}
\hline Logika PIN 2 & LED PIN 13 \\
\hline 1 & HIGH \\
0 & LOW \\
\hline
\end{tabular}

Keterangan:

High $=$ Nyala

Low $=$ Mati

\subsubsection{Pengujian Sensor Ultrasonik}

Pada proses pengujian sensor ultrasonik HC SR04 dilakukan dengan menghubungkan sensor ultrasonik HC SR04 dengan mikrokontrol arduino uno sebagai pengolah sinyal dengan memasukkan coding tertentu. Sebelum dicoding pin Vcc dan gnd sensor disambungkan dengan pin $5 \mathrm{~V}$ dan gnd arduino, kemudian pin trigger ultrasonik dengan pin 9 arduino uno, dan pin echo dihubungkan ke pin 8 arduino uno. Rangkaian interface dapat dilihat pada Gambar 11. 


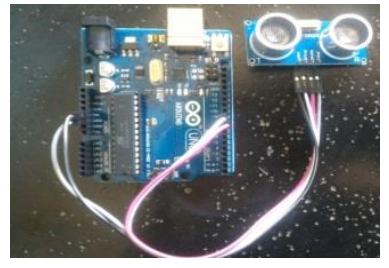

Gambar 11. Iinterface arduino dengan sensor ultrasonik

Setelah di hubungkan maka sensor ultrasonik dapat diuji dengan menggunakan penggaris untuk mengetahui apakah sesuai atau ada selisih. Seperti pada Gambar 12, dari hasil pengujian sensor ultrasonik dapat ditampilkan pada Serial Monitor yang ada pada program IDE

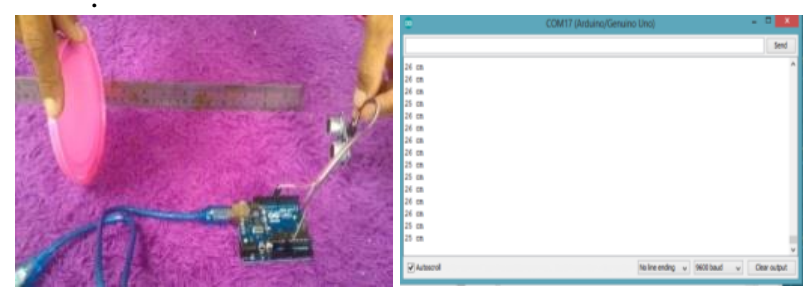

Gambar 12. Pengujian sensor ultrasonik

\subsubsection{Pengujian LCD (Liquid Crystal Display)}

Pengujian pada LCD (Liquid Crystal Display) dilakukan dengan cara memasukkan coding program pada fungsi main(). Pengujian LCD berhasil dilakukan, ditunjukkan dengan munculnya karakter pada LCD sesuai dengan coding

\subsubsection{Pengujian Sensor Photodioda}

Pengujian sensor photodioda dilakukan dengan menghubungkan sensor dengan mikrokontroller arduino uno sebagai pengolah sinyal dengan memasukkan coding tertentu. Sebelum dicoding perlu dibuat sebuah rangkaian sederhana seperti pada Gambar 13, menyambungkan pin Vcc dan gnd sensor dengan pin $5 \mathrm{~V}$ dan gnd serta pin 3 dari arduino uno, kemudian hasil pengujian sensor dapat ditampilkan pada LCD.

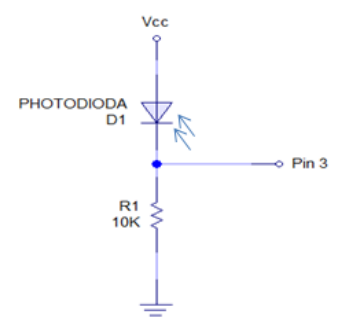

Gambar. 13. Rangkaian photodiode

\subsubsection{Pengujian Buzzer}

Pada tahap pengujian ini buzzer dipasang di ruang petugas sebagai peringatan ketika kondisi tempat sampah telah mencapai batas yang telah ditentukan maka buzzer akan berbunyi,

Pemasangan buzzer ini untuk mengetahui apakah buzzer dapat dijadikan Output pada arduino. Pada buzzer terdapat 2 kabel merah dan hitam, merah untuk dihubungkan ke pin 5 Volt pada arduino kemudian kabel warna hitam dihubungkan ke pin 3 pada arduino uno. Gambar 14 menunjukkan buzzer yang telah dihubungkan ke arduino sebagai output. Hasil pengujian buzzer dapat dilihat pada tabel 3 .

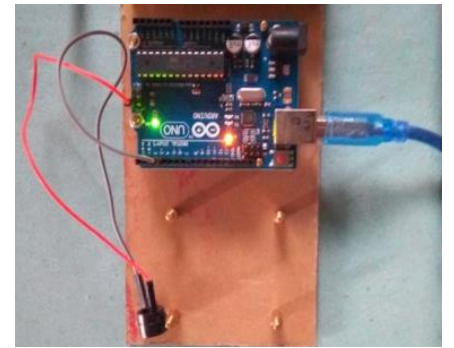

\section{Gambar 14. Buzzer sebagai Output Arduino}

Tabel 3. Hasil Pengujian Buzzer

\begin{tabular}{ll}
\hline Logika PIN 6 & Buzzer \\
\hline 1 & High (Bunyi) \\
0 & Low (Mati) \\
\hline
\end{tabular}

\subsubsection{Pengujian Xbee}

Pada pengujian xbee yang dibutuhkan adalah mengatur konfigurasi pada software xctu sesuai dengan apa yang dibutuhkan, apakah xbee akan dijadikan coordinator, router atau end device karena xbee ini bisa digunakan sebagai pengirim (transmitter) dan penerima (receiver)

\subsubsection{Pengujian Keseluruhan}

Pengujian keseluruhan alat yaitu dengan menggabungkan keseluruhan perangkat keras meliputi arduino uno, Xbee, sensor ultrasonik, sensor photo dioda pada tempat sampah dan arduino uno, Xbee, buzzer, lcd serta laptop untuk menampilkan program. Setelah perangkat keeluruhan digabung selanjutnya dimasukkan coding pada masing masing bagian. Bagian Router (RW 1 dan 2) dimasukkan coding data yang akan dikirim dan bagian Coordinator di masukkan coding data yang akan diterima ketika dikirimkan oleh router agar mengetahui kondisi tempat sampah pada RW 1 dan RW 2.

Setelah di gabung dan di masukkan coding sesuai perencanaan dan di koneksikan bagian master, maka tampilan delphi sebagai pemantau nirkabel didapatkan sesuai pada gambar 15 .

Kondisi tempat sampah dan lampu penerangan jalan akan terpantau terus pada sistem monitoring Hasil pengujian 
alat sesuai pada Tabel 4 dan 5 , keadaan tempat sampah dapat dilihat pada progres bar sedangkan untuk kondisi lampu dapat dilihat pada indikator kondisi lampu.

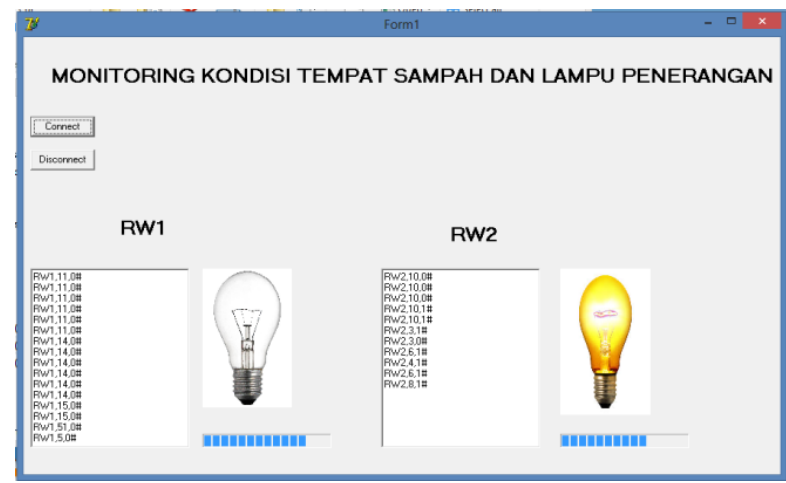

Gambar 15. Tampilan sistem monitoring pada laptop

Alamat RW1,11,0\# menunjukkan bahwa alamat yang dikirim adalah dari RW 1 , selanjutnya adalah kondisi kedaan tempat sampah dimana 11 menunjukkan jarak sampah ke sensor adalah 11 centimeter, ketika jarak sampah sudah mencapai 5 centimeter atau dibawahnya maka progres bar akan berwarna biru hampir penuh sehingga buzzer di ruang petugas akan berbunyi. Dan berikutnya adalah kondisi keadaan lampu penerangan jalan ketik lampu dalam kondisi mati maka alamat yang dikirimkan adalah 0 dan indikator lampu berwarna putih sedangkan ketika lampu penerangan jalan dalam kondisi menyala maka alamat yang akan dikirimkan adalah 1 serta indikator lampu pada sistem monitoring akan menyala. Tanda \# diakhir alamat yang diterima menunjukkan akhir data yang telah dikirim, sehingga ketika sudah menerima kode \# berarti satu paket data telah lengkap diterima oleh sistem.

Tabel 4. Hasil sistem monitoring di RW 1

\begin{tabular}{|c|c|c|c|c|}
\hline Alamat & $\begin{array}{l}\text { Kondisi } \\
\text { Tempat } \\
\text { Sampah }\end{array}$ & $\begin{array}{l}\text { Keadaan } \\
\text { Tempat } \\
\text { sampah }\end{array}$ & $\begin{array}{l}\text { Kondisi } \\
\text { Lampu }\end{array}$ & $\begin{array}{c}\text { Keterangan } \\
\text { Keadaan } \\
\text { Lampu }\end{array}$ \\
\hline RW1,11,0\# & 11 & $\begin{array}{c}\text { Isi sampah } \\
11 \mathrm{~cm} \text { dari } \\
\text { sensor }\end{array}$ & 0 & Mati \\
\hline RW1,14,0\# & 14 & $\begin{array}{l}\text { Isi sampah } \\
14 \mathrm{~cm} \text { dari } \\
\text { sensor }\end{array}$ & 0 & Mati \\
\hline RW1,15,0\# & 15 & $\begin{array}{l}\text { Isi sampah } \\
15 \mathrm{~cm} \text { dari } \\
\text { sensor }\end{array}$ & 0 & Mati \\
\hline RW1,5,0\# & 5 & $\begin{array}{l}\text { Isi sampah } \\
5 \mathrm{~cm} \text { dari } \\
\text { sensor, } \\
\text { Keadaan } \\
\text { hampir } \\
\text { penuh }\end{array}$ & 0 & Mati \\
\hline
\end{tabular}

Tabel 5. Hasil sistem monitoring di RW 2

\begin{tabular}{|c|c|c|c|c|}
\hline Alamat & $\begin{array}{l}\text { Kondisi } \\
\text { Tempat } \\
\text { Sampah }\end{array}$ & $\begin{array}{c}\text { Keadaan } \\
\text { Tempat sampah }\end{array}$ & $\begin{array}{l}\text { Kondisi } \\
\text { Lampu }\end{array}$ & $\begin{array}{c}\text { Keterangan } \\
\text { Keadaan } \\
\text { Lampu }\end{array}$ \\
\hline RW2,10,0\# & 10 & $\begin{array}{c}\text { Isi sampah } \\
10 \mathrm{~cm} \text { dari sensor }\end{array}$ & 0 & Mati \\
\hline RW2,3,1\# & 3 & $\begin{array}{l}\text { Isi sampah } \\
3 \mathrm{~cm} \text { dari sensor, } \\
\text { Keadaan penuh }\end{array}$ & 1 & Nyala \\
\hline RW2,6,1\# & 6 & $\begin{array}{c}\text { Isi sampah } \\
6 \mathrm{~cm} \text { dari sensor } \\
\text { Keadaan hampir } \\
\text { penuh }\end{array}$ & 1 & Nyala \\
\hline RW2,4,1\# & 4 & $\begin{array}{c}\text { Isi sampah } \\
4 \mathrm{~cm} \text { dari sensor, } \\
\text { Keadaan penuh }\end{array}$ & 1 & Nyala \\
\hline RW2,8,1\# & 8 & $\begin{array}{c}\text { Isi sampah } \\
8 \mathrm{~cm} \text { dari sensor, } \\
\text { Keadaan hampir } \\
\text { penuh }\end{array}$ & 1 & Nyala \\
\hline
\end{tabular}

\subsection{Sistem Dengan Topologi Jaringan Star}

Pengujian dengan menggunakan prinsip topologi jaringan star ini dapat dilihat pada Gambar 16 dimana setiap node/router mempertahankan satu jalur komunikasi langsung dengan coordinator. Pada bagian ini dibuat 2 buah node/router (RW 1 dan 2) kemudian dimasukkan coding data yang akan dikirim ke bagian Coordinator dan dimasukkan coding data yang akan diterima ketika dikirimkan oleh node/router agar mengetahui kondisi tempat sampah pada RW 1 dan RW 2.

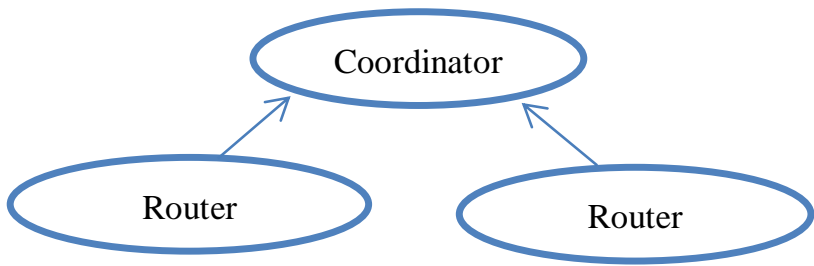

Gambar 16. Prinsip topologi jaringan star

Setiap router akan mengirimkan informasi keadaan tempat sampah secara kontinyu ke coordinator dimana respon jarak maksimal yang bisa ditempuh dari router ke coordinator dengan posisi indoor maupun outdoor dan hasil pengujian dapat dilihat pada dalam Tabel 6 dan 7 .

Tabel 6. Pengujian jarak jangkauan Coordinator ke Router RW1 dan RW2 indoor

\begin{tabular}{cccc}
\hline No & $\begin{array}{c}\text { Jarak } \\
\text { (meter) }\end{array}$ & Data Kirim & Status \\
\hline 1 & 6 & RW 1 dan RW 2 & Terkirim \\
2 & 10 & RW 1 dan RW 2 & Terkirim \\
3 & 15 & RW 1 dan RW 2 & Terkirim \\
4 & 20 & RW 1 dan RW 2 & Terkirim \\
5 & 30 & RW 1 dan RW 2 & Terkirim \\
6 & 35 & RW 1 dan RW 2 & SulitTerkirim \\
7 & 40 & RW 1 dan RW 2 & Tidak terkirim \\
\hline
\end{tabular}


Dari hasil pengujian jarak jangkauan coordinator ke router dilakukan pengukuran setiap 5 meter sesuai tabel 6 menunjukkan jarak aman komuniksi indoor adalah 30 meter.

Tabel 7. Pengujian jarak jangkauan Coordinator ke Router RW1 dan RW2 outdoor

\begin{tabular}{ccc}
\hline Jarak (meter) & Data kirim & status \\
\hline 5 & RW 1 dan RW 2 & Terkirim \\
10 & RW 1 dan RW 2 & Terkirim \\
15 & RW 1 dan RW 2 & Terkirim \\
20 & RW 1 dan RW 2 & Terkirim \\
25 & RW 1 dan RW 2 & Terkirim \\
30 & RW 1 dan RW 2 & Terkirim \\
45 & RW 1 dan RW 2 & Terkirim \\
50 & RW 1 dan RW 2 & Terkirim \\
55 & RW 1 dan RW 2 & Terkirim \\
60 & RW 1 dan RW 2 & Terkirim \\
65 & RW 1 dan RW 2 & Terkirim \\
70 & RW 1 dan RW 2 & Terkirim \\
75 & RW 1 dan RW 2 & Terkirim \\
80 & RW 1 dan RW 2 & Terkirim \\
85 & RW 1 dan RW 2 & Tidak Terkirim \\
\hline
\end{tabular}

Dari hasil pengujian jarak jangkauan coordinator ke router dilakukan pengukuran setiap interval 5 meter sesuai tabel 7 menunjukkan jarak aman komuniksi outdoor adalah 80 meter.

\subsection{Sistem Dengan Topologi Jaringan Bus}

Pada tahap pengujian ini diadopsi prinsip topologi jaringan Bus, seperti pada Gambar 17 dimana setiap node/router berfungsi sebagai repeater (penguat) sinyal yang akan dikirim oleh end device, sedangkan repeater tidak bisa membaca sensor.

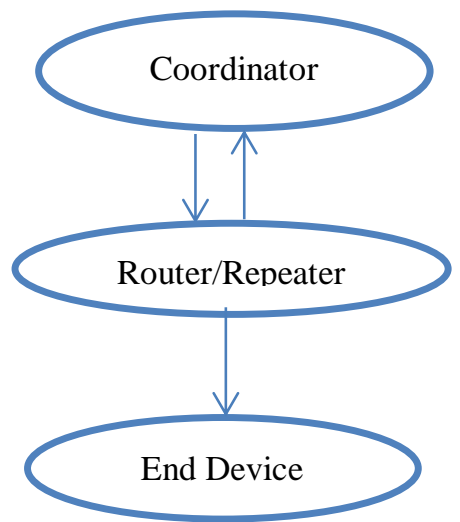

Gambar 17. Prinsip topologi jaringan Bus

Dengan prinsip ini maka komunikasi dapat dilakukan dengan jarak yang jauh tergantung dengan banyak nya repeater, Ketika kondisi end device berada dijangkauan jarak dari coordinator maka end device bisa langsung mengirimkan data ke coordinator akan tetapi ketika end device berada sangat jauh dari jangkauan coordinator disini repeater akan berfungsi menguatkan sinyal kiriman data dari end device. Untuk hasil pengujian respon jarak indoor maupun outdoor dapat dilihat pada dalam tabel 8 dan 9 .

Tabel 8. Pengujian jarak jangkauan Coordinator-Repeater dan end device

\begin{tabular}{cccc}
\hline No & $\begin{array}{c}\text { Jarak } \\
\text { (meter) }\end{array}$ & Data Kirim & Status \\
\hline 1 & 6 & RW 1 & Terkirim \\
2 & 10 & RW 1 & Terkirim \\
3 & 15 & RW 1 & Terkirim \\
4 & 20 & RW 1 & Terkirim \\
5 & 30 & RW 1 & Terkirim \\
6 & 35 & RW 1 & Terkirim \\
7 & 40 & RW 1 & Terkirim \\
8 & 45 & RW 1 & Terkirim \\
3 & 50 & RW 1 & Terkirim \\
4 & 55 & RW 1 & Terkirim \\
5 & 60 & RW 1 & Terkirim \\
6 & 65 & RW 1 & Sulit Terkirim \\
7 & 70 & RW 1 & Tidak Terkirim \\
\hline
\end{tabular}

Hasil pengujian jarak jangkauan Coordinator-Repeater dan end device dengan prinsip topologi bus menggunakan end device sebagai media nirkabel dilakukan pengukuran setiap interval 5 meter sesuai Tabel 8 menunjukkan jarak aman komuniksi indoor adalah 60 meter.

Tabel 9. Pengujian jarak jangkauan Coordinator Repeater dan end device

\begin{tabular}{|c|c|c|c|}
\hline No & Jarak (meter) & Hasil & Keterangan \\
\hline 1 & 5 & RW 1 & Terkirim \\
\hline 2 & 10 & RW 1 & Terkirim \\
\hline 3 & 15 & RW 1 & Terkirim \\
\hline 4 & 20 & RW 1 & Terkirim \\
\hline 5 & 25 & RW 1 & Terkirim \\
\hline 6 & 30 & RW 1 & Terkirim \\
\hline 7 & 45 & RW 1 & Terkirim \\
\hline 8 & 50 & RW 1 & Terkirim \\
\hline 9 & 55 & RW 1 & Terkirim \\
\hline 10 & 60 & RW 1 & Terkirim \\
\hline 11 & 65 & RW 1 & Terkirim \\
\hline 12 & 70 & RW 1 & Terkirim \\
\hline 13 & 75 & RW 1 & Terkirim \\
\hline 14 & 80 & RW 1 & Terkirim \\
\hline 15 & 85 & RW 1 & Terkirim \\
\hline 16 & 90 & RW 1 & Terkirim \\
\hline 17 & 95 & RW 1 & Terkirim \\
\hline 18 & 100 & RW 1 & Terkirim \\
\hline 19 & 105 & RW 1 & Terkirim \\
\hline 20 & 110 & RW 1 & Terkirim \\
\hline 21 & 115 & RW 1 & Terkirim \\
\hline 22 & 120 & RW 1 & Terkirim \\
\hline 23 & 125 & RW 1 & Terkirim \\
\hline 24 & 130 & RW 1 & Terkirim \\
\hline 25 & 135 & RW 1 & Terkirim \\
\hline 26 & 140 & RW 1 & Terkirim \\
\hline 27 & 145 & RW 1 & Terkirim \\
\hline 28 & 150 & RW 1 & Terkirim \\
\hline 29 & 155 & RW 1 & Terkirim \\
\hline 30 & 160 & RW 1 & Sulit Terkirim \\
\hline 31 & 165 & RW 1 & Tidak Terkirim \\
\hline
\end{tabular}

Hasil pengujian jarak jangkauan Coordinator-Repeater dan end device dengan prinsip topologi bus 
menggunakan end device sebagai media nirkabel dilakukan pengukuran setiap interval 5 meter sesuai Tabel 9 menunjukkan jarak aman komuniksi outdoor adalah 155 meter.

\section{Kesimpulan}

Setelah melalui tahap pengujian pada sistem monitoring kondisi tempat sampah dan lampu penerangan jalan dengan melalui komunikasi berbasis wireles sensor network (wsn) menggunanakan Xbee S2 (Zigbee) sebagai pemancar dan penerima sinyal maka dihasilkan kesimpulan sebagai berikut. Sesuai perancangan perangkat Xbee $S 2$ dapat digunakan sebagai pengirim (transmitter) dan penerima (receiver) data pada sistem monitoring keadaan tempat sampah dan lampu penerengan jalan melalui komunikasi nirkabel. Dari percobaan yang dilakukan jarak aman jangkauan Xbee s2(Zigbee) sejauh 30 meter indoor dan 80 meter outdoor dengan menggunakan prinsip topologi star. Sedangkan jika menggunakan prinsip topologi bus jarak jangkauannya bisa lebih jauh dua kali lipat yaitu sejauh 60 meter indoor dan 155 meter outdoor. Pendeteksian volume sampah berdasarkan perhitungan jarak sensor ultrasonik telah sukses memberikan (mengirimkan) notifikasi berupa buzzer dan tampilan pada software interface dengan jarak kurang dari atau sama dengan $5 \mathrm{~cm}$

Penulis memberikan saran kepada pihak yang ingin mengembangkan sistem monitoring ktempat sampah rumah tangga dan lampu penerangan jalan berbasis wireles sensor network (wsn) menggunanakan Xbee S2 (Zigbee) sebagai pemancar dan penerima sinyal untuk menggunakan komunikasi dengan wifi untuk jangkauan jarak yang lebih jauh lagi. Selain itu, aplikasi android untuk tampilan peringatan dapat ditambahkan.

\section{Referensi}

[1]. J. Liu and J. Luo, "Method of Wireless Sensor Network Data Fusion," Int. J. Online Eng., vol. 13, pp. 114-122.

[2]. F. L. Lewis, "Wireless Sensor Networks," Smart Environ. Technol. Protoc. Appl., pp. 1-18, 2005.

[3]. C. H. Andre Gunther, "Measuring Round Trip Times to Determine the Distance between WLAN Nodes," Telecommun. Networks Gr., no. May, pp. 1-12, 2005.

[4]. T. I. N. Ahmad Deny Andika, Poltak Sihombing, "Perancangan Sistem Pengukur Jarak Antara 2 Titik Wireless Xbee Pro Berdasarkan Nilai RSSI Ahmad," vol. VOL1-6, no. 6, pp. 3-8, 2012.

[5]. T. S. Dedi Setiawan and M. Iqbal, "Rancang bangun alat pembuka dan penutup tong sampah otomatis berbasis mikrokontroler," Teknol. dan Sist. Inf., vol. 1, no. 1, pp. 55-62, 2014.

[6]. K. A. Monika, N. Rao, S. B. Prapulla, and G. Shobha, "Smart Dustbin-An Efficient Garbage Monitoring System," Int. J. Eng. Sci. Comput., vol. 6, no. 6, pp. 7113-7116, 2016.

[7]. M. D. Eko Ihsanto, "Sistem Monitoring Lampu Penerangan Jalan Umum Menggunakan Mikrokontroler Arduino Dan Sensor Ldr Dengan Notifikasi Sms," Int. Stand. Ser. Number, vol. 7, no. 2, pp. 101-105, 2016.

[8]. A. Kadir, panduan praktis mempelajari aplikasi mikrokontroler dan pemrogramannya menggunakan arduino, vol. 1. Yogyakarta: C.V ANDI OFFSET, 2012.

[9]. L. N. Hilmi Wijayanti, "Rancang Bangun 'Smart Dustbin'Berbasis Arduino Sebagai Alat Pembelajaran Anak Usia Dini," Tek. Telekomun., no. 1231130021, 2015.

[10]. R. Hasta, "Aplikasi Teknologi Komunikasi Wireless Berbasis Zigbee Pada Sistem Kontrol Dan Monitoring Ruangan Kelas," J. Ilm. GIGA Vol., vol. 18, no. 1, pp. 70-81, 2015.

[11]. N. Muljodipo, S. R. U. A. Sompie, R. F. Robot, M. Eng, J. T. Elektro-ft, and E. Nuryantomuljodipogmailcom, "Rancang Bangun Otomatis Sistem Infus Pasien," Ejournal Tek. Elektro dan Komput. ISSN 2301-8402, vol. 4, no. 4, pp. 12-22, 2015.

[12]. P. Rafiuddin Syam, ST, M.Eng, Dasar Dasar Teknik Sensor. Makasar: Fakultas Teknik Universitas Hasanuddin, 2013.

[13]. G. K. Bhasworo, F. Rofii, and F. Hunaini, "Perancangan Sistem Pemantauan Gas dan Peringatan pada Ruangan melalui Jaringan Nirkabel," vol. 37, no. 2, pp. 88-93, 2016. 